\section{BISMA}

(Bisnis dan Manajemen)
Volume 11, Nomor 1, Oktober 2018, 33-46

ISSN 2549-7790 (Online)

ISSN 1979-7192 (Print)

https://journal.unesa.ac.id/index.php/bisma/index

\title{
Ketertarikan dan Persepsi Mahasiswa Fakultas Ekonomika dan Bisnis untuk Bekerja di Usaha Kecil Menengah
}

\author{
Etni Marliana ${ }^{1}$ \\ Universitas Muria Kudus ${ }^{1}$ \\ Email korespondesi: etni.marliana@umk.ac.id
}

\begin{abstract}
Small and Medium Enterprises (SMEs) has an exceptionally important role in Indonesian economic development. However, SMEs are facing some challenges due to the lack of qualified human resources to work in this sector. This research is designed to identify the perception of business school students in working with SMEs. Furthermore, it also shows how SMEs is perceived to offer the job factors that are important for the students to determine a job. The sampling method used was purposive sampling method. The data were collected by primary data collection through questionnaires. Data analysis was performed with the Wilcoxon Signed Rank Test. The result showed that business school students are less attracted to work with SMEs compared to large enterprises. Furthermore, students perceive that SMEs are better than large enterprises only in terms of quality and managerial relationship, authority, and involvement in decision making. It is also perceived by the students that compare to large enterprise SMEs offer fewer job factors that are viewed to be important to determine a job.
\end{abstract}

Keywords: job factors; large enterprises; SMEs; students perception; working preference

Received: 24 Juli 2018

Reviewed: 20 Agustus 2018

Accepted: 13 September 2018

Published: 31 Oktober 2018

\section{PENDAHULUAN}

Usaha Kecil Menengah (UKM) memiliki peranan penting sebagai tulang punggung perekonomian Indonesia. Laporan Bank Indonesia (2015), menyebutkan bahwa UKM memberikan kontribusi setidaknya 59\% terhadap Pendapatan Domestik Bruto. Dengan jumlah pelaku usaha sebanyak 56,54 juta unit, sektor ini merupakan $99,99 \%$ dari total keseluruhan pelaku usaha di Indonesia. Dengan proporsi tersebut, UKM diperkirakan mampu menyediakan lapangan pekerjaan untuk 85-107 juta orang. Dalam menjalankan usahanya, UKM lebih banyak menggunakan bahan baku lokal dan tidak memiliki hutang dalam bentuk dolar (Hapsari et al. 2014). Oleh karena itu saat dihadapkan pada krisis 
finansial, Indonesia mampu mempertahankan keadaan ekonomi salah satunya dikarenakan kekuatan UKM menjaga indikator ekonomi makro (Seran, 2016).

Meskipun memiliki peran yang penting dalam perekonomian, tidak berarti UKM terbebas dari tantangan untuk bisa berkembang. Keterbatasan modal, minimnya akses informasi terhadap pasar, dan teknologi yang kurang modern menjadi tantangan-tantangan yang sering dihadapi oleh banyak UKM (Fatimah, 2011). Persoalan utama lain yang menghambat pertumbuhan UKM adalah keterbatasan sumber daya manusia (SDM) baik dari segi kuantitas maupun kualitas (Haase dan Lautenshlanger, 2011). Jumlah SDM yang dapat direkrut oleh tiap UKM masih terbatas dikarenakan kondisi finansial perusahaan yang tidak cukup kuat untuk menggaji banyak pekerja. Sedangkan kendala kualitas SDM yang sering dihadapi oleh UKM misalnya saja (1) pengetahuan tentang teknologi produksi dan pengecekan kualitas produk yang kurang memadahi; (2) SDM UKM belum memiliki kemampuan yang cukup untuk melihat kondisi pasar serta memanfaatkan perkembangan media sosial dan internet sebagai media pemasaran; (3) pemilik UKM belum memiliki rencana jangka panjang untuk usahanya (Bank Indonesia, 2015).

Tanpa sumber daya manusia yang berkualitas UKM akan semakin sulit untuk berkembang dan berkompetisi dengan usaha lain termasuk juga dengan usaha besar. Oleh karena itu, kompetensi SDM dalam hal pengetahuan, keterampilan, serta keahlian manajerial harus dimiliki oleh pemilik UKM dan juga setiap individu yang bekerja di UKM (Ardiana et al. 2010). Para lulusan universitas (sarjana) berpotensi untuk menjadi sumber daya yang tepat dan berharga untuk mengembangkan UKM. Selama perkuliahan mereka dibekali dengan pengetahuan dan keterampilan yang memungkinkan untuk diterapkan di UKM. Ketika para sarjana bekerja di UKM, terdapat dampak positif yang dirasakan oleh sektor ini. Manfaat tersebut dapat dikelompokkan berdasarkan jangka waktunya (Sear et al. 2012). Dalam jangka pendek UKM setidaknya bisa memanfaatkan langsung keterampilan yang dimiliki oleh para sarjana. Berkat pendidikan di universitas, para sarjana memiliki keterampilan untuk belajar dengan cepat, melihat gambaran besar suatu permasalahan, dan bekerja secara tim maupun individual (Hart dan Barrat, 2009). Hal-hal tersebut bisa membantu UKM untuk mengidentifikasi serta beradaptasi dengan perubahan yang terjadi di pasar. Untuk jangka menengah, para sarjana membantu meningkatkan kemampuan UKM dalam meningkatkan hasil usaha dan inovasi. Mereka mampu menyumbang ide-ide dan menemukan cara baru yang lebih baik untuk menggantikan cara kerja yang lama (Archer dan Davison, 2008). Selebihnya dalam jangka panjang, UKM yang mempekerjakan sarjana akan memiliki kinerja dan produktivitas bisnis yang baik. Dengan demikian, pertumbuhan dan keuntungan yang lebih tinggi dapat diraih (Chiliya dan Lombard, 2012). Penelitian juga menemukan bahwa lulusan universitas dapat menjadi pembuka koneksi antara UKM dengan kalangan akademis dan profesional lain. Disamping itu, sarjana yang bekerja di UKM 
dianggap memiliki nilai jual tinggi serta dapat meningkatkan citra UKM (Hart \& Barrat, 2009).

Mengingat banyaknya pengaruh positif yang mungkin diberikan, UKM perlu merekrut para sarjana bagi usaha mereka. Namun demikian, UKM menghadapi kesulitan untuk mengajak sarjana yang berkompeten untuk bergabung. Para mahasiswa tidak menjadikan pilihan bekerja di UKM sebagai prioritas pertama ketika mereka lulus dari universitas (Kantabutra dan Jariangprasert, 2012; Vilathuvahna dan Nugroho, 2015). Mereka lebih tertarik untuk bekerja di perusahaan besar seperti di perusahaan multinasional atau bekerja sebagai Pegawai Negeri Sipil (PNS) dari pada bekerja mengembangkan UKM. Di sisi lain, minat mahasiswa untuk menjadi wirausahawan juga masih sangat rendah. Hanya terdapat sekitar 355,2 ribu mahasiswa (7,4\%) dari 4,7 juta mahasiswa yang berminat mendirikan usaha sendiri (Kemenkop UKM, 2012 dalam Mopangga, 2014). Ketertarikan yang rendah untuk bergabung disebabkan oleh karena banyaknya pandangan negatif yang dimiliki para sarjana terhadap UKM (Sukri dan Roslan, 2013) terutama dari segi gaji. Penelitian oleh Kok et al. (2011) yang dilakukan di 28 negara Eropa dan Amerika Serikat menemukan bahwa para karyawan di UKM mendapatkan gaji yang lebih rendah daripada di usaha besar. Selisih gaji antara kedua sektor tersebut bervariasi yang bahkan dapat mencapai $40 \%$.

\section{Persepsi terhadap UKM}

Penelitian yang secara khusus membahas ketertarikan sarjana untuk bekerja di sektor UKM masih sangat terbatas (Hart \& Barrat, 2009). Hanya terdapat beberapa penelitian sebelumnya yang berusaha membandingkan minat kerja mahasiswa untuk bekerja di UKM dengan sektor usaha lain (Moy dan Lee, 2002; Grubb III et al. 2007; Kantabutra dan Jariangprasert, 2012). Hasilnya menemukan bahwa bekerja di UKM setelah lulus merupakan alternatif yang dipilih apabila mahasiswa tidak berhasil bergabung dengan sektor usaha lain yang dianggap lebih menjanjikan. Sebagian besar mahasiswa setelah lulus ingin bekerja di usaha besar maupun organisasi pemerintah (Kantabutra dan Jariangprasert, 2012). Vilathuvahna dan Nugroho (2015) melakukan penelitian terhadap mahasiswa di Universitas Trunojoyo, hasilnya ditemukan bahwa hanya 17\% mahasiswa memiliki keinginan untuk menjadi wirausahawan setelah lulus, lainnya (83\% mahasiswa) berkeinginan untuk menjadi PNS, dosen, jurnalis dan bekerja di tempat lain.

Jurusan ketika kuliah juga terlihat memberikan pengaruh terhadap minat mahasiswa untuk bergabung dengan UKM. Van der Sijde et al. (2013) menemukan bahwa mahasiswa lulusan sekolah bisnis di Belanda lebih berminat untuk bekerja di sektor UKM jika dibandingkan dengan mahasiswa jurusan lain. Sebagian besar mahasiswa jurusan lain lebih tertarik untuk bekerja di usaha besar. 
Namun demikan, apabila terdapat kondisi yang sesuai, mahasiswa jurusan lain bersedia mempertimbangkan kembali pilihan untuk dapat bergabung di UKM.

\section{Faktor Pekerjaan}

Terdapat berbagai banyak faktor yang mempengaruhi seorang mahasiswa untuk memilih tempat bekerja setelah lulus kuliah. Faktor-faktor tersebut misalnya saja ekspektasi luaran (outcome expectation), jenis kelamin, ketertarikan pribadi, pengalaman pendidikan, relasi, dan agama (Edward dan Quinter, 2011). Ekspektasi luaran merupakan faktor pekerjaan yang terkait dengan perusahaan secara langsung serta merupakan manfaat yang diharapkan oleh karyawan dari suatu pekerjaan. Di samping ekspektasi luaran beberapa peneliti menggunakan istilah faktor pekerjaan untuk mengetahui persepsi mahasiswa terhadap UKM dan usaha besar. Oleh 395 mahasiswa bisnis di Amerika Serikat, UKM dipandang lebih baik dalam menawarkan faktor pekerjaan dalam hal kondisi kerja, hubungan dan kualitas manajerial, kewenangan yang dimiliki, serta keterlibatan dalam pembuatan keputusan. Sedangkan faktor pekerjaan yang berupa gaji, tunjangan, prospek karir jangka panjang, marketability, keamanan kerja (job security), dan tanggung jawab dipersepsikan dapat ditawarkan secara lebih baik oleh usaha besar (Grubb III et al. 2007). Selain itu, penelitian terhadap mahasiswa empat universitas di Chiang Mai (Thailand) oleh Kantabutra dan Jariangprasert (2012) juga memberikan hasil yang hampir sama. Mahasiswa di universitas-universitas di Chiang Mai mempersepsikan bahwa bekerja di UKM dan usaha besar akan berbeda dari segi gaji, tanggung jawab, ketertarikan (interest), prospek karir jangka panjang, marketability, dan tunjangan.

Beberapa faktor pekerjaan yang dianggap paling penting dalam menentukan pekerjaan adalah gaji, keamanan kerja, tunjangan, dan prospek karir jangka panjang (Kantabutra dan Jariangprasert, 2012). Namun demikian, gaji tidak selalu menjadi faktor utama memilih pekerjaan. Terdapat lulusan sekolah bisnis yang menganggap bahwa kebebasan berkreasi, tanggung jawab, dan pekerjaan multidisipin merupakan faktor yang lebih penting untuk memilih suatu pekerjaan (Van der Sijde et al. 2013).

Hasil penelitian yang berbeda memberikan gambaran bahwa persepsi mahasiswa dan lulusan universitas terhadap faktor pekerjaan di UKM dan usaha besar cukup berbeda antara satu negara dengan negara lainnya. Perbedaan hasil ini mungkin diakibatkan karena perbedaan kondisi UKM dan usaha besar antar negara. Di Belanda lulusan sekolah bisnis tidak menganggap adanya perbedaan mencolok antara kedua sektor tersebut dari segi gaji, sehingga mereka memprioritaskan faktor lain dalam menentukan pekerjaan (Van der Sijde et al. 2013). Agar dapat bersaing dalam mendapatkan tenaga kerja yang kompeten, pelaku UKM di Indonesia perlu mengetahui ketertarikan serta pandangan para calon tenaga kerja terhadap usahanya serta pesaingnya (usaha besar). Oleh sebab itu, penelitian ini dirancang dengan tujuan untuk (1) mengetahui minat kerja 
mahasiswa setelah mereka lulus kuliah (2) membandingkan persepsi mahasiswa terhadap UKM dan usaha besar (3) mengetahui faktor-faktor yang dianggap penting dalam menentukan sebuah pekerjaan. Hasil penelitian ini diharapkan dapat membantu UKM menemukan cara agar mahasiswa memiliki ketertarikan serta pandangan yang lebih positif terhadap pilihan karir di UKM.

\section{METODE PENELITIAN}

Penelitian ini merupakan penelitian yang bersifat deskriptif kuantitatif. Data primer yang digunakan dalam analisis berasal dari hasil kuesioner. Subjek penelitian ini adalah mahasiswa Fakultas Ekonomika dan Bisnis di sebuah universitas di kota Yogyakarta. Pengambilan sampel dilakukan secara tidak acak menggunakan metode purposive sampling dimana kriteria tertentu dipakai untuk memilih sampel. Kriteria yang digunakan dalam pemilihan sampel adalah mahasiswa tingkat akhir yang minimal sedang duduk di semester 7. Diharapkan sampel tersebut dapat memberikan informasi yang lebih baik karena dalam waktu dekat mereka akan segera lulus dan masuk pasar tenaga kerja.

Secara keseluruhan kuesioner dibagi menjadi empat bagian. Bagian pertama digunakan untuk mengumpulkan data demografis dari responden. Bagian kedua mengukur ketertarikan mahasiswa untuk bekerja di UKM dan usaha besar dengan menggunakan tiga item pertanyaan yang diadaptasi dari penelitian oleh Chow dan Ngo (2011). Bagian ketiga, mengukur persepsi mahasiswa tentang seberapa baik faktor pekerjaan dapat ditawarkan oleh UKM dan usaha besar. Faktor pekerjaan tersebut terdiri dari gaji, tunjangan, kondisi kerja, kualitas dan hubungan manajerial, prospek karir jangka panjang, tanggung jawab yang diberikan, kewenangan, keterlibatan dalam pembuatan keputusan, marketability, dan job security (Moy dan Lee, 2002; Grubb III et al. 2007; Kantabutra dan Jariangprasert, 2012). Pada bagian keempat, responden diminta untuk menilai seberapa penting faktor pekerjaan tersebut dalam memilih suatu pekerjaan. Skala likert 5 poin digunakan untuk menilai indikator-indikator yang digunakan pada kuesioner bagian kedua sampai dengan keempat.

\section{Definisi Operasional}

UKM dan usaha besar dibedakan berdasarkan beberapa karakteristik. Bank dunia membedakan kedua sektor tersebut berdasarkan jumlah pekerja. Sedangkan di Indonesia menurut UU No. 20 tahun 2008 keduanya dikelompokkan berdasarkan nilai aset dan omset tahunan (Bank Indonesia, 2015). Pembagaian kriteria tersebut dapat dilihat pada tabel 1. 
Tabel 1. Kriteria UKM dan Usaha Besar

\begin{tabular}{llll}
\hline \multirow{2}{*}{ Jenis Usaha } & \multicolumn{1}{c}{ Bank Dunia } & \multicolumn{2}{c}{ UU No. 20 Tahun 2008 } \\
\cline { 2 - 4 } & Jumlah Karyawan & \multicolumn{1}{c}{ Aset } & \multicolumn{1}{c}{ Omset Tahunan } \\
\hline Usaha kecil & $<30$ orang & Rp 50 juta -500 juta & Rp 500 juta-10 milyar \\
\hline Usaha menengah & $30-300$ orang & Rp 500 juta-10 milyar & Rp 2,5 milyar -50 milyar \\
\hline Usaha Besar & $>300$ orang & $>$ Rp 10 milyar & $>$ Rp 50 milyar \\
\hline
\end{tabular}

Sumber: Bank Indonesia (2015)

Berdasarkan kriteria dari Bank Dunia dan UU yang berlaku di Indonesia, maka UKM dapat didefinisikan sebagai usaha ekonomi yang dilakukan oleh orang perorangan atau badan usaha yang bukan merupakan anak perusahaan atau cabang usaha besar dan memiliki jumlah karyawan dibawah 300 orang, jumlah aset senilai Rp 50 juta - 10 milyar, atau hasil penjualan tahunan sebesar Rp 500 juta 50 milyar. Sedangkan usaha besar didefinisikan sebagai usaha ekonomi yang dilakukan oleh badan usaha dan memiliki jumlah karyawan lebih dari 300 orang dan jumlah aset lebih dari Rp 10 milyar atau hasil penjualan tahunan lebih dari $\mathrm{Rp}$ 50 milyar.

Adapun faktor pekerjaan yang digunakan dalam penelitian memiliki definisi sebagai berikut. (1) Gaji merupakan kompensasi berupa uang yang diterima oleh pegawai sebagai imbalan karena berkerja di dalam suatu organisasi. (2) Tunjangan adalah kompensasi di luar gaji yang diberikan secara tidak langsung kepada pegawai (misalnya saja berupa asuransi kesehatan dan jiwa, dana pensiun, dan fasilitas kantor). (3) Kondisi pekerjaan adalah keadaan lingkungan yang berkaitan dengan keamanan dan kenyamanan kerja. (4) Kualitas dan hubungan manajerial merupakan relasi antara pegawai dengan atasannya. (5) Prospek karir jangka panjang adalah kesempatan promosi ditawarkan oleh perusahaan kepada karyawan di masa depan. (6) Tanggung jawab yang diberikan adalah kewajiban yang harus dilakukan oleh karyawan dalam pekerjaannya. (7) Kewenangan adalah hak yang diberikan kepada karyawan untuk memberikan arahan dan mengatur pekerjaannya. (8) Keterlibatan dalam pembuatan keputusan adalah kesempatan yang diberikan kepada pegawai untuk berpartisipasi dalam proses memutuskan sesuatu. (9) Marketability adalah kesempatan pegawai untuk mengembangkan keterampilan sesuai dengan permintaan pasar. (10) Job security adalah perlindungan yang dirasakan oleh karyawan dikarenakan adanya jaminan risiko kehilangan pekerjaan, pemberhentian atau pemecatan.

Penelitian ini menggunakan uji beda untuk mencari apakah ketertarikan mahasiswa bekerja di UKM dan usaha besar berbeda secara signifikan. Untuk mengetahui jenis uji beda yang dipakai, dilakukan uji normalitas guna mengetahui persebaran data. Dari hasil pengujian dengan menggunakan Kolmogrov-Smirnov diketahui bahwa data tidak terdistribusi normal. Karena data tidak berdistribusi normal dan sampel yang digunakan adalah related sampel, maka jenis uji beda yang digunakan adalah Wilcoxon Signed Rank Test (Sekaran dan Bougie, 2017).

Dalam uji Wilcoxon Signed Rank Test data dari ketertarikan mahasiswa untuk bekerja di UKM akan dibandingkan dengan data ketertarikan mahasiswa 
untuk bekerja di usaha besar. Uji beda dalam penelitian ini menggunakan tingkat signifikansi $(\alpha) 0,05$. Ada atau tidaknya perbedaan yang signifikan antara kategori data yang dibandingkan dapat dilihat dari nilai $\mathrm{p}$ ( $p$-value). Apabila setelah dihitung menggunakan Wilcoxon Signed Rank Test nilai $p \leq 0,05$, artinya terdapat perbedaan yang signifikan antara kategori data yang dibandingkan. Sedangkan apabila nilai $p>0,05$ berarti tidak terdapat perbedaan yang signifikan dari kategori data yang diuji. Tahapan dan jenis uji beda yang sama juga digunakan untuk mengidentifikasi apakah terdapat perbedaan yang signifikan dari persepsi mahasiswa terhadap kemampuan UKM dan usaha besar dalam menawarkan kesepuluh faktor pekerjaan. Selanjutnya, pemberian ranking berdasarkan nilai mean digunakan untuk mengidentifikasi faktor-faktor pekerjaan mana yang dianggap penting bagi mahasiswa dalam bekerja.

\section{HASIL DAN PEMBAHASAN}

\section{Ketertarikan terhadap UKM dan Usaha Besar}

Dari sebanyak 150 kuesioner dibagikan dalam penelitian, terdapat 120 kuesioner yang dapat diolah. Sejumlah 30 kuesioner tidak dapat digunakan karena data yang tidak lengkap atau responden yang tidak memenihi persyaratan minimal sedang duduk di semester 7 . Responden perempuan berjumlah sebanyak 67 orang $(55,8 \%)$ sedangkan responden laki-laki berjumah 53 orang $(44,2 \%)$. Berdasarkan jurusan kuliahnya, responden berasal dari tiga kelompok yaitu jurusan akuntansi (45 orang), manajemen (45 orang), dan ilmu ekonomi (30 orang).

Pengujian menggunakan Wilcoxon Signed Rank Test (Tabel 2) menunjukkan bahwa terdapat perbedaan yang signifikan antara ketertarikan mahasiswa bekerja di UKM dan usaha besar $(Z=-8,715 ; \mathrm{p} \leq 0,05)$. Untuk mengetahui ketertarikan terhadap usaha manakah yang lebih tinggi dapat dilihat dari nilai mean. Nilai mean yang lebih tinggi menunjukkan bahwa perusahaan tersebut lebih diminati oleh para mahasiswa. Mean ketertarikan mahasiswa untuk bekerja di UKM (mean $=2,89$ ) memiliki nilai yang lebih rendah jika dibanding dengan di usaha besar (mean $=4,21$ ). Dengan keadaan tersebut, dapat dibuktikan bahwa mahasiswa memiliki ketertarikan yang lebih rendah untuk bekerja di UKM dibanding usaha besar setelah lulus dari universitas.

Hasil penelitian menunjukkan bahwa ketika masuk di pasar tenaga kerja, para lulusan universitas lebih tertarik untuk mendapatkan perkerjaan di perusahaan besar daripada di UKM. Hal ini menguatkan penelitian-penelitian lain yang dilakukan oleh diungkapkan oleh Kantabutra dan Jariangprasert (2012) serta Vilathuvahna dan Nugroho (2015). Walaupun demikian, terdapat juga mahasiswa memiliki ketertarikan cukup tinggi untuk untuk bekerja di sektor UKM. Dimungkinkan mahasiswa-mahasiswa tersebut biasanya mengasosiasikan ketertarikan bekerja di UKM dengan ketertarikan mendirikan UKM (berwirausaha). 
Tabel 2. Perbandingan Mean Ketertarikan Mahasiswa Bekerja

\begin{tabular}{lrrrrr}
\hline & \multicolumn{2}{c}{ Mean } & \multirow{Z}{*}{$\boldsymbol{p}$} & \multirow{2}{*}{ Ket. } \\
\cline { 2 - 5 } & UKM & Usaha Besar & & $\boldsymbol{p}$ & \\
\hline Ketertarikan untuk bekerja & 2,89 & 4,21 & $-8,715^{*}$ & 0,000 & Signifikan \\
\hline${ }^{*}$ Berdasarkan ranking negatif & & & & & \\
\hline Sumber: Data primer diolah & & & & &
\end{tabular}

\section{Persepsi Mahasiswa terhadap Faktor Pekerjaan}

Perbandingan persepsi mahasiswa terhadap faktor pekerjaan di UKM dan usaha besar dapat dilihat pada tabel 3. Hasi uji Wilcoxon Signed Rank Test menunjukkan bahwa terdapat perbedaan yang signifikan antara persepsi mahasiswa terhadap faktor pekerjaan yang ditawarkan UKM dan usaha besar $(\mathrm{p} \leq 0,05)$. Mahasiswa memiliki pandangan bahwa beberapa faktor pekerjaan mampu ditawarkan secara lebih baik oleh UKM. Namun di samping itu, banyak faktor lainnya dipersepsikan dapat diberikan dengan lebih baik oleh usaha besar.

Tabel 3: Perbandingan Mean Persepsi Mahasiswa terhadap Faktor Pekerjaan di UKM dan Usaha Besar

\begin{tabular}{|c|c|c|c|c|c|}
\hline \multirow{2}{*}{ Faktor pekerjaan } & \multicolumn{2}{|r|}{ Mean } & \multirow{2}{*}{$Z$} & \multirow{2}{*}{$p$} & \multirow{2}{*}{ Ket. } \\
\hline & UKM & Usaha besar & & & \\
\hline Gaji & 3,13 & 4.15 & $-8,463^{*}$ & 0,000 & Signifikan \\
\hline Tunjangan & 2,74 & 4,12 & $-8,679^{*}$ & 0,000 & Signifikan \\
\hline Kondisi kerja & 3,34 & 3,65 & $-3,115^{*}$ & 0,002 & Signifikan \\
\hline $\begin{array}{l}\text { Kualitas dan hubungan } \\
\text { manajerial }\end{array}$ & 3,83 & 3,52 & $-2,442^{* *}$ & 0,015 & Signifikan \\
\hline Prospek karir jangka panjang & 3,08 & 4,12 & $-6,906^{*}$ & 0,000 & Signifikan \\
\hline Tanggung jawab yang diberikan & 3,66 & 3,89 & $-2,427^{*}$ & 0,015 & Signifikan \\
\hline Kewenangan & 3,91 & 3,23 & $-5,459^{* *}$ & 0,000 & Signifikan \\
\hline $\begin{array}{l}\text { Keterlibatan dalam pembuatan } \\
\text { keputusan }\end{array}$ & 3,73 & 3,25 & $-4,262^{* * *}$ & 0,000 & Signifikan \\
\hline Marketability & 3,43 & 3,78 & $-3,237^{*}$ & 0,001 & Signifikan \\
\hline Job security & 3,07 & 3,85 & $-5,823^{*}$ & 0,000 & Signifikan \\
\hline $\begin{array}{l}{ }^{*} \text { Berdasarkan ranking negatif } \\
* * \text { Berdasarkan ranking positif }\end{array}$ & & & & & \\
\hline
\end{tabular}

Sumber: Data primer diolah

Hasil penelitian menunjukkan bahwa mahasiswa mempersepsikan UKM lebih baik daripada usaha besar dalam hal menawarkan kualitas dan hubungan manajerial, keterlibatan dalam pembuatan keputusan, dan kewenangan. Pada ketiga faktor pekerjaan tersebut, nilai mean faktor pekerjaan di UKM lebih tinggi daripada usaha besar. Sedangkan usaha besar dianggap lebih baik dalam lebih banyak faktor pekerjaan lainnya yang ditunjukkan dengan nilai mean lebih tinggi. Faktor pekerjaan tersebut adalah gaji, tunjangan, kondisi kerja, prospek karir jangka panjang, tanggung jawab yang diberikan, marketability, dan job security.

UKM dipersepsikan memiliki kualitas dan hubungan manajerial yang lebih baik dibandingkan dengan usaha besar. Ukurannya yang kecil menjadikan karyawan lebih mudah berinteraksi dengan pemilik UKM untuk menyampaikan ide maupun permasalahan yang dihadapi. Lebih jauh lagi karyawan juga bisa 
secara langsung belajar tentang organisasi dari pemilik UKM. Hal tersebut membawa dampak positif pada level komunikasi dan kepercayaan antara pemilik UKM dengan karyawannya sehingga terbangun hubungan manajerial yang baik (Cheng, et al. 2016). Jumlah anggota yang lebih sedikit juga membuat struktur organisasi menjadi lebih datar dan birokrasi menjadi tidak terlalu rumit dalam UKM. Dampaknya pekerja lebih mudah dilibatkan dalam proses pembuatan keputusan baik dalam hal operasional harian maupun penentuan langkah stratejik perusahaan. Kewenangan yang diberikan UKM dipersepsikan lebih baik mungkin dikarenakan karyawan UKM diberikan kebebasan yang lebih luas untuk mengambil tindakan terkait dengan pekerjaan.

UKM dipandang memiliki keterbatasan dalam hal finansial karena jumlah modal dan omsetnya yang tidak setinggi usaha besar. Akibatnya, mahasiswa menilai bahwa jika bekerja di sektor UKM mereka akan menerima tingkat kompensasi (gaji dan tunjangan) pada tingkat yang lebih rendah dibandingkan di usaha besar (Moy dan Lee, 2002; Kantabutra dan Jariangprasert, 2012). Persepsi ini mungkin terbangun dari kondisi yang mahasiswa lihat di masyarakat dimana orang yang bekerja di usaha besar biasanya memiliki kondisi keuangan yang lebih baik dibanding mereka yang bekerja di UKM. Prospek karir jangka panjang di usaha besar dipandang lebih baik dari pada di UKM. Di dalam usaha besar, terdapat struktur organisasi yang cukup tinggi dengan berbagai macam tingkatan jabatan. Hal ini dikarenakan banyaknya jumlah pekerja di usaha tersebut. Mahasiswa memandang bahwa dengan banyaknya tingkatan jabatan, maka pegawai usaha besar juga memiliki kesempatan untuk mencapai posisi-posisi yang lebih tinggi semakin lama dia bekerja di sektor tersebut.

Untuk faktor tanggung jawab, mahasiswa mempersepsikan bahwa pekerjaan pada usaha besar akan memiliki tanggung jawab yang lebih baik dibandingkan dengan UKM. Hasil ini berbeda dengan hasil penelitian yang dikemukakan oleh Cheng et al. (2016). Tugas di usaha besar sudah dibagi berdasarkan posisi sehingga sulit untuk bisa diserahkan kepada pihak lain tanpa adanya ijin atau pendelegasian dari atasan. Dengan demikian, seorang pekerja usaha besar akan memiliki tanggung jawab yang lebih jelas dan terbatas pada posisinya.

Mahasiswa juga mempersepsikan bahwa kondisi marketability dan job security di usaha besar akan lebih baik daripada di UKM. Di usaha besar karyawan dipersepsikan memiliki kesempatan lebih luas untuk mendapatkan pelatihan keterampilan-keterampilan yang dibutuhkan. Selain itu, bekerja di usaha besar juga dirasa dapat memberikan kepastian dalam hal memberikan kelangsungan pekerjaan yang lebih stabil. Kemungkinan kehilangan pekerjaan karena PHK akibat kondisi perusahaan yang buruk, dipandang lebih sulit untuk terjadi di usaha besar. 


\section{Faktor Pekerjaan yang Dianggap Penting}

Dalam memilih pekerjaan, persepsi dan preferensi (ketertarikan) terhadap tempat kerja merupakan hal yang sangat penting untuk dijadikan pertimbangan (Van der Sijde, et al 2013). Persepsi terhadap bagaimana faktor pekerjaan ditawarkan di sebuah pekerjaan dapat mempengaruhi keputusan seseorang menentukan pekerjaan. Oleh karena itu, penelitian ini juga mengidentifikasi faktor yang dianggap penting oleh mahasiswa dalam suatu pekerjaan. Dari sepuluh faktor pekerjaan yang digunakan, diambil lima faktor tertinggi. Kelima faktor pekerjaan yang dianggap paling penting dalam menentukan pekerjaan oleh mahasiswa adalah (1) prospek karir jangka panjang (mean=4,53); (2) kondisi kerja (mean=4,35); (3) job security (mean=4,32); (4) gaji (mean=4,24); dan (5) kualitas dan hubungan manajerial (mean=4,13).

Hasil penelitian menunjukkan bahwa prospek karir jangka panjang merupakan faktor pekerjaan yang dianggap paling penting dalam pemilihan pekerjaan. Hal ini dianggap penting karena dengan kesempatan mendapatkan promosi dan posisi yang lebih tinggi, kedepannya pegawai juga akan dimungkinkan memperoleh pendapatan yang lebih besar serta status sosial yang lebih tinggi. Hasil tersebut berbeda dengan Kantabutra, S. dan Jariangprasert (2012) serta Hossain dan Siddique (2012) yang menemukan bahwa faktor yang paling utama bagi mahasiswa dalam memilih pekerjaan adalah gaji dan kompensasi keuangan.

Faktor kedua yang dianggap penting adalah kondisi kerja. Tanpa lingkungan kerja yang nyaman akan sulit bagi seseorang untuk termotivasi dalam menjalankan pekerjaannya. Penelitian sebelumnya oleh Van der Sijde, P. (2013) juga menemukan bahwa para pencari kerja di Belanda memberikan penekanan penting pada kebebasan dan kondisi kerja yang baik.

Job security merupakan faktor ketiga yang dianggap cukup perlu diperhatikan dalam memilih pekerjaan. Mendapatkan pekerjaan bukanlah suatu hal yang mudah. Oleh karena itu, mahasiswa mengharapkan keamanan dari sebuah tempat pekerjaan dimana mereka bisa bekerja dalam jangka waktu yang lama dan bebas dari ancaman kebangkrutan. Hal ini menjelaskan alasan mahasiswa lebih berminat untuk menjadi PNS daripada bekerja di sektor UKM (Vilathuvahna dan Nugroho, 2015).

Faktor pekerjaan selanjutnya yang diperhatikan adalah gaji. Temuan ini cukup menarik karena ternyata dalam menentukan pekerjaan, mahasiswa kurang memperhatikan keuntungan jangka pendek yang bisa didapatkan dari kompensasi. Gaji akan meningkat seiring dengan karir seseorang. Oleh karena itu mahasiswa lebih mengutamakan prospek karir jangka panjang dalam menentukan pekerjaan. Temuan ini sesuai dengan hasil penelitian Lautenschlager \& Haase (2010) yang menyatakan bahwa individu di Jerman menganggap pendapatan dan status sosial tinggi bukan merupakan hal yang paling penting. Selain keempat faktor tersebut, 
faktor kualitas dan hubungan manajerial menjadi hal selanjutnya yang dirasa penting diperhatikan oleh mahasiwa untuk memilih pekerjaan.

Ketertarikan bekerja mahasiswa untuk bekerja di UKM maupun usaha besar terbentuk dari persepsi mahasiswa tentang bagaimana kedua sektor tersebut mampu menawarkan faktor pekerjaan yang dianggap penting. Dari kelima faktor yang dianggap paling penting oleh mahasiswa untuk memilih pekerjaan, empat diantaranya dipersepsikan ditawarkan secara lebih baik oleh usaha besar. Hanya satu faktor - yaitu kualitas dan hubungan manajerial - yang dianggap dapat diberikan dengan lebih baik oleh UKM. Hal ini kemungkinan dapat menjelaskan alasan mahasiswa memiliki ketertarikan yang lebih rendah untuk bekerja di UKM.

Oleh karena persepsi akan mempengaruhi preferensi tempat kerja, maka UKM dituntut untuk bisa memperbaiki persepsi mahasiswa terhadap usahanya agar bisa menarik lebih banyak sumber daya manusia yang berkualitas. UKM harus mampu menyampaikan dan membuktikan kepada mahasiswa bahwa faktor pekerjaan yang dianggap penting dapat ditawarkan di usahanya. Misalnya saja prospek karir jangka panjang dapat ditawarkan UKM dengan memberikan promosi berdasarkan bukan hanya berdasarkan lama bekerja tetapi berdasarkan kinerja karyawan. Selain itu, penamaan jenis jabatan juga merupakan hal lain lain yang perlu diperhatikan dalam promosi oleh UKM. Untuk kaitannya dengan kondisi kerja, UKM dapat menawarkan fleksibilitas guna meningkatkan kenyamanan lingkungan kerja. Fleksibilitas yang diberikan dapat berupa pilihan untuk bekerja dari rumah (working from home) atau kesempatan dalam menentukan jam dan jadwal bekerja. Selanjutnya untuk meningkatkan kondisi faktor job security UKM, harus tersedia kontrak kerja yang jelas yang memuat status karyawan, prosedur pemutusan hubungan kerja dan juga kompensasinya. Dengan demikian karyawan merasa bahwa pekerjaannya akan aman di UKM.

Tingginya perbedaan ketertarikan untuk bekerja di usaha besar dan UKM juga menjadi tantangan bagi kalangan akademis untuk menemukan alternatif agar setelah lulus mahasiswa yang berkompeten bersedia bekerja mengembangkan sektor UKM. Kerjasama yang baik antara universitas dan UKM perlu dilakukan untuk lebih mengenalkan UKM kepada mahasiswa. Hal ini dapat dilakukan dengan memberikan kesempatan kepada UKM untuk berpartisipasi dalam kegiatan universitas yang berupa kunjungan perusahaan, job fair, dan penawaran magang. Diharapkan adanya interaksi dengan UKM, dapat membuat mahasiswa memiliki persepsi dan ketertarikan yang lebih baik terhadap sektor ini.

\section{KESIMPULAN}

Pentingnya peran UKM dalam perekonomian Indonesia, menuntut sektor ini untuk dapat merekrut SDM berkualitas guna mengembangkan usahanya. Para mahasiswa yang lulus dari universitas dianggap sebagai calon tenaga kerja yang memiliki kompetensi yang dibutuhkan oleh UKM. Namun demikian, dari penelitian ini diketahui bahwa mahasiswa lebih tertarik untuk bekerja di usaha 
besar daripada di UKM. Oleh mahasiswa UKM dipersepsikan lebih baik daripada usaha besar dalam hal kualitas dan hubungan manajerial, kewenangan, serta keterlibatan dalam pembuatan keputusan. Sedangkan usaha besar dipersepsikan lebih baik daripada UKM dalam hal gaji, tunjangan, kondisi kerja, prospek karir jangka panjang, tanggung jawab yang diberikan, marketability, dan job security. Lima faktor yang dianggap penting dalam menentukan pekerjaan adalah prospek karir jangka panjang, kondisi kerja, job security, gaji, kualitas dan hubungan manajerial.

Ketertarikan yang lebih rendah terhadap UKM dapat dijelaskan dengan konsep persepsi dan preferensi. Dari lima faktor yang dianggap penting bagi mahasiswa, UKM dianggap lebih baik daripada usaha besar hanya dalam satu faktor yaitu kualitas dan hubungan manajerial. Keempat faktor penting lainnya dipersepsikan dapat ditawarkan secara lebih baik oleh usaha besar. Oleh karena itu, mahasiswa lebih memprioritaskan untuk bisa mendapat pekerjaan di usaha besar setelah lulus. Mahasiswa merasa bahwa usaha besar lebih mampu untuk memenuhi apa yang mereka anggap penting. Penelitian ini hanya meneliti ketertarikan mahasiswa untuk bekerja di UKM dan usaha besar. Untuk mendapatkan gambaran yang lebih mendetail penelitian selanjutnya dapat membedakan ketertarikan mahasiswa untuk mendirikan UKM (berwirausaha), bekerja di UKM dan juga ketertarikan mahasiswa bekerja di sektor lain (misalnya sebagai PNS). Penelitian lain juga perlu dilakukan untuk melihat apakah faktorfaktor lain seperti gender, latar belakang pendidikan (jurusan maupun tingkat pendidikan), dan lama bekerja mempengaruhi ketertarikan dan persepsi terhadap UKM. Disamping itu, ketertarikan UKM untuk mempekerjakan para sarjana juga perlu diteliti lebih lanjut.

\section{REFERENSI}

Ardiana, I.D.K.R., Brahmayanti, L.A. dan Subaedi. 2010. Kompetensi SDM UKM dan Pengaruhnya Terhadap Kinerja UKM di Surabaya. Jurnal Manajemen dan Kewirausahaan, 12 (1): 42-55.

Archer, W., Davison, J. 2008. Graduate Employability: What Do Employers Think and Want? Council for Industry and Higher Education: London.

Bank Indonesia. 2015. Profil Usaha Mikro, Kecil dan Menengah (UMKM). https://www.bi.go.id/id/umkm/penelitian/nasional/kajian/Documents/Profil \%20Bisnis\%20UMKM.pdf., diakses tanggal 6 Mei 2018.

Cheng, R., Lourenço, F., dan Resnick, S. 2016. Educating graduates for marketing in SMEs: An update for the traditional marketing curriculum. Journal of Small Business and Enterprise Development, 23 (2): 495-513

Chiliya, N. dan Lombard, M.R. 2012. Impact of Level of Education and Experience Profitability of Small Grocery Ships in South Africa. 
International Journal of Business Management and Economic Research, 3 (1): 462-470.

Chow, I.H.S. dan Hang-yue Ngo. 2011. Gender Differences in Job Atrribute Preferences and Job Choice of University Students in China. The Journal of Applied Business Research, 18 (2): 16-25.

Edwards, K. dan Quinter, M. 2011. Factors Influencing Students Career Chioce among Secondary Students in Kisumu Municipality, Kenya. Journal of Emerging Trends in Educational Research and Policy Studies, 2 (2): 81-87.

Fatimah, J. 2011. Strategi Pemberdayaan Usaha Mikro, Kecil dan Menengah (UMKM) dalam Menghadapi Globalisasi. Econo Sains, 9 (1), 49-60.

Grubb III, W.L., Harris, M.L. dan MacKenzie, Jr. W.I. 2007. Business Students' Perception of Employment in Small and Medium-Sized Enterprises Versus Multinational Corporation: Investigating the Moderating Effects od Academic Major, Gender, and Personality. Journal of Small Business Strategy, 17 (2): 27-35.

Haase, H. dan Lautenschlager, A. 2011. Career Choice Motivation of University Students. International Journal of Business Administration, 2 (Februari): 213.

Hart, T., Barratt, P. 2009. The Employment of Graduates within Small and Medium-sized Firms in England, People, Place and Policy Online, 3 (1): pp. $1-15$.

Hapsari, P.P., Hakim, A. Soeaidy, S. 2014. Pengaruh Pertumbuhan Usaha Kecil Menengah (UKM) terhadap Pertumbuhan Ekonomi Daerah (Studi di Pemerintah Kota Batu). Wacana, 17 (3): 88-96.

Hossain, M.E. dan Siddique, T. 2012. Career Preference of Business Graduate in Bangladesh: A Case Study of Some Selected Private Universities. Asian Business Review, 1(1): 106-113.

Kantabutra, S. dan Jariangprasert, N. 2012. Perception of Student Towards Working with Small and Medium Sized Enterprises: A Case Study of Chiang Mai and Luang Prabang. Business and Information: 339-348.

Kok, J.D., et al. 2011. Do SMEs create more and better jobs?. EIM Business \& Policy Research: Zoetermeer.

Lautenschlager, A., \& Haase, H. 2010. Universities: a hotbed of human resources for new firms? Journal of Small Business and Entrepreneurship, 23(special issue): 747-759.

Mopangga, H. 2014. Faktor Determinan Minat Wirausaha Mahasiswa Fakultas Ekonomi dan Bisnis Universitas Negeri Gorontalo. Trikonomika, 13 (1): 7890. 
Moy, J.W. dan Lee, S.M. 2002. The Career Choice of Business Graduates: SMEs or MNCs. Career Development, 7 (6): 339-347.

Sear, L., Tracy S., Janine S., dan Simon D. 2012. Graduate Recruitment to SMEs Final Report. SFEDI: County Durham.

Sekaran, U. dan Bougie, R. 2017. Metode Penelitian untuk Bisnis. Salemba Empat: Jakarta.

Seran, S., 2016. Pendidikan dan Karakteristik Pelaku UMKM Serta Kontribusinya Terhadap Perekonomian Nasional. Jurnal Pendidikan Bisnis dan Manajemen, 2 (1): 12 - 26

Sukri, S., dan Roslan, N. S. 2013. The Study of Students' Perception of Working for Small and Medium Enterprises (SMEs). International Conference on Business Innovation, Entrepreneurship and Engineering. Penang, 2013. 114.

Van der Sijde, P., Nair, P., dan During, W. 2013. Graduates' Perception of Employment in SMEs and Large Enterprises. International Journal of Business and Social Science, 4 (6). 15-20.

Vivathuvahna, A.A. dan Nugroho, T.R.D.A. 2015. Intensi Kewirausahaan Mahasiswa Universitas Trunojoyo Madura. Agriekonomika, 4 (1). 107-119. 